\title{
Chapter 1 \\ On the Reflexive Relations Between \\ Knowledge, Governance, and Space
}

\author{
Johannes Glückler, Gary Herrigel, and Michael Handke
}

Governance is both a contested concept and an increasingly empirical concern. On the one hand, it has become an almost universal and all-encompassing concept, which has attracted scholarly interest from many disciplines and over many decades to tackle the dilemmas of collective action and to facilitate effective coordination of interests and resources toward commonly accepted goals. On the other hand, conceptions of governance vary considerably, and their meanings depend on disciplinary perspectives, theoretical traditions, and empirical focus. Although it is easy to agree what governance is not, it is more challenging to create broad consensus on what it is and how it works effectively. Most capaciously, governance denotes the coordination of collective action. These actions take place in institutionally or physically organized spaces of interaction, where knowledge is needed to shape governance appropriately. Organized spaces and knowledge are both conditions as well as consequences of the governance process.

Contributions to theories and perspectives of governance originate from diverse disciplinary fields, including political science, economics, organization studies, sociology, geography, and planning studies. The authors of recent handbooks provide comprehensive overviews of the interdisciplinary breadth of ideas and debates of governance (e.g., Ansell \& Torfing, 2016; Bache \& Flinders, 2004; Bevir, 2010; Chhotray \& Stoker, 2009; Levi-Faur, 2012). They portray the multitude of applications and concepts, ranging from practical fields such as corporate, contract, project, public, private, or nonprofit governance, to internet, land, urban, risk, environmental, and climate governance, to conceptual or normative approaches of network,

\footnotetext{
J. Glückler $(\bowtie) \cdot$ M. Handke

Department of Geography, Heidelberg University, Heidelberg, Germany e-mail: glueckler@uni-heidelberg.de; handke@uniheidelberg.de

G. Herrigel

Department of Political Science, University of Chicago, Chicago, IL, USA

e-mail: g-herrigel@uchicago.edu
} 
collaborative, participative, fair or good governance, and to various levels ranging from local to regional and national to global and multilevel governance.

Sometimes, it is helpful for an emergent concept not to be defined too narrowly in order to attract continuous attention and research effort and to stimulate scholarly conversation. Yet such diversity may also make it difficult for researchers to exchange, compare, and assess empirical studies on common ground. Therefore, governance research often remains locked within a discipline's cognitive boundaries. Governance debates always comprise a selection of perspectives. Debaters view the complex reality in a certain way, concentrating on selected characteristics and neglecting other ones (Benz \& Dose, 2010). The polysemy of the concept of governance confronts scholars with the difficult task of coherently theorizing the social, political, environmental, institutional, and economic challenges to collective action.

We are positioning our book at the neglected intersection between disciplines, conceptual perspectives, and geographical scales to offer room for conversation on the role of knowledge and space in governance theory and practice. We are bringing together conceptual and empirical work on governance from varying fields, and the contributions' authors not only illustrate the multidisciplinary character of governance research, but they also point to new opportunities for interdisciplinary exchange. We argue for-and the chapters each speak to- particular aspects of the reflexive nature of the relationships between governance, knowledge, and space. In the next section, we briefly define an inclusive framing of some of the characteristics of governance, before we elaborate on the reflexive relations between governance, knowledge and space. By doing so, we highlight the contributions of the individual chapters of this volume to each of these relations, which also provide the rationale for structuring the book into distinct parts.

\section{Framing Governance}

Rather than unnecessarily restricting the concept of governance, we propose carving out some of its commonly shared characteristics by means of comparison with related notions in social science, such as management, government, and institutions. All three concepts relate to mechanisms that yield and sustain some degree of social order. Utilizing the governance perspective sheds new conceptual light on these concepts by emphasizing the process character of coordinating and moderating organized social interactions. Governance represents relational practices. There is governance inside firms and across firms, and there is governance within governments and across government boundaries. Governance also coordinates between firms and governments. However, unlike management or government, governance is not an actor capable of making decisions. Rather, it offers a reliable structure for interaction, which is something that it has in common with institutions (Glückler, Suddaby, \& Lenz, 2018). In many cases, these structures have yet to be established and institutionalized by the actors involved in governance practices, which once again leads back to the process character of governance (Pierre \& Peters, 2000). 
To capture the specific meaning of governance, we place it on a conceptual continuum that expands along the dimensions of time (from long-term to short-term convertibility) and of authority (from heteronomy or interdependence to autonomy). Concretely, we conceive governance as lying between the concepts of institutions on one end of longer term societal coordination, and of management as well as of government on the other end of shorter term coordination and decision making within the scope of a single authority (organization, state).

Researchers use the concept of institutions to describe relatively stable patterns of social interactions that are based on legitimate mutual expectations and that are enforced by social sanctions (Barley \& Tolbert, 1997; Glückler et al., 2018; Hodgson, 2006; Scott, 2007). Institutions refer to legitimate beliefs and practices that are shared to varying degrees by society, guarantee social order, offer behavioral orientation, and facilitate individual action within society. It is, therefore, difficult for individuals or organizations to actively change or overturn existing institutions (Lawrence, Leca, \& Zilber, 2013), and if so only over longer periods. Institutional change often unfolds incrementally and only in exceptional cases can it be interpreted ex post as the result of specific moments that disrupted the reproduction of institutional practices, and which then gave rise to collective strategies to recompose rules and institutional features (Glückler \& Lenz, 2018; Herrigel, 2010; Streeck \& Thelen, 2005).

Whereas institutions are characterized by relative temporal stability and usually slow rates of transformation, the other end of the continuum comprises shorter term, current forms of coordination by means of management. Researchers use "management" to describe the administration of an organization, including the choice of a strategy and the coordination of all the resources in pursuit of the organization's objective. Consequently, management is a coordination mode bounded within the scope of and legitimized by one single authority. Managers are entitled to take decisions within their organizational jurisdiction and thus are empowered to allocate resources, design organizational structures and processes, to assign roles and responsibilities, to solve conflicts, and allocate resources in pursuit of the organization's goals.

Governance should also not be confused with government (Osborne \& Gaebler, 1992; Rosenau \& Czempiel, 1992), which also provides hierarchical order. A republican form of government, for example, is composed of temporary legitimated representatives who execute the power of the state and, similarly to management, internally assign roles and allocate resources towards collective goals. These goals have grown in number and diversity in modern societies, disproportionately increasing intervention costs for the state. However, being a prominent object of study in conceptual government research (Kooiman, 1993), hierarchical structures often become encrusted and retain decision making in the silos of specific knowledge domains. Government thus risks failing to appropriately address contemporary collective problems, especially if they transcend different functional and territorial jurisdiction (Mayntz, 2003). Meanwhile, modern governments are increasingly confronted with the idea that sovereignty lies with the people and not with their 
representatives - what role, then, can a government play as an actor in governance processes?

In contrast to longer term and less dirigible institutions on the one hand, and hierarchically controllable shorter term management or temporarily elected governments on the other, we conceive governance as the coordination of distinct stakeholders toward the achievement of consensual goals. These stakeholders might be legally independent of each other, but interdependently linked by a collective problem. In contrast to management or government, governance extends beyond the scope of the rule enforcement of a single authority, and, hence, requires negotiation between different interests (Rhodes, 1996). In governance, those affected by rules are themselves involved in the design of regulation and their institutional enforcement (Marin \& Mayntz, 1991). In this way, governance differs from social institutions in that creators of governance processes actively and purposively tackle collective action problems to find acceptable solutions. Such a broad understanding of interdependent controllability or "heterarchy" (Jessop, 1998), including negotiation, collaboration, and legitimacy, is supported in most governance approaches.

\section{Knowledge and Governance}

Governance attracts much of its attention as an analytical perspective because it is used to address learning processes in changing environments (Stoker, 1998). The relationship between knowledge and governance is reflexive in nature: Knowledge is a prerequisite for governance as much as governance affects how one creates or shares knowledge. Being at the core of this book series, the concept of knowledge denotes the human understanding of concrete and abstract phenomena. Whereas people can keep "stocks" and exchange "flows" of data and information, the creation of knowledge is initially bound to the individual mind. However, individuals are not atomistic, isolated actors, but embedded in social and institutional contexts. People constantly compare and align their understandings with the understandings of others, and engage in imitation and communication to challenge or confirm common understanding. When framing knowledge as a relational rather than a substantive concept of human understanding, knowledge is difficult to produce in isolation, to store or protect from spillovers, or to copy and reuse in other contexts (Bathelt \& Glückler, 2011; Glückler, Meusburger, \& El Meskioui, 2013). Whereas knowledge represents the practice of knowing, knowledge creation emerges from the practice of learning, the circulation and interpretation of information, cumulative experience, and cognition (Amin \& Cohendet, 2004; Borgatti \& Cross, 2003). In this sense, the dynamics of knowing and learning are fundamentally social and most often interactive processes (Lundvall \& Johnson, 1994). It includes the collective creation of knowledge as well as its imitation through others. Researchers have acknowledged learning as a reflexive, interactive, and continuous process of recombining knowledge towards new understanding. However, learning is focused on more than just the recombination of existing knowledge. Bridging the barriers to 
communication between different communities is important (Nooteboom, 2000), but so is collective learning across the boundaries of thought collectives to generate new knowledge for new solutions (Fleck, 1935; Herrigel, Wittke, \& Voskamp, 2013; Punstein \& Glückler, 2020). Knowledge in governance can be seen as both an input and a collective outcome that is newly created (Hess \& Ostrom, 2007). The joint learning process reinforces the positive aspects of interdependence among otherwise loosely coupled actors.

Both knowledge and learning are contextual rather than universal (Bathelt \& Glückler, 2011; Meusburger, 2008), which makes effective governance processes a truly complex challenge. Knowledge is hard to store or accumulate and difficult to value. The production of knowledge and recognizing its value (utility) in common depend on the social and spatial context. Governance is always an arranged relational practice. The authors of much of the economic governance literature refer to governance arrangements as "mechanisms." These include markets, hierarchies, and relational contracts (Williamson, 2005). Others also include networks as governance arrangements (Keast, 2016; Powell, 1991). The economic arguments, however, often remain very abstract and are therefore difficult to relate to the common usage of the concept in other disciplines. In the following, we elaborate on the reflexive relationship between knowledge and governance in more detail and divide the book into three parts. The authors of the first two parts refer to the role of knowledge for governance. Whereas those of the first section discuss how knowledge enables governance organization, those of the second analyze how knowledge for governance influences its impact and efficacy. In turn, the third part is a collection of conceptual and empirical contributions that discuss how governance affects learning processes and how it generates new knowledge to solve collective problems. The individual book chapters complement each other thematically and with their analytical emphasis on specific problems of coordinating collective actions.

\section{How Knowledge Enables Governance}

The development and implementation of effective governance solutions often requires bringing together distinct knowledge about the collective problem. A precise definition of the problem is often not possible from the very beginning and thus becomes an explicit goal of the governance process. Knowledge can be mobilized and recombined either by drawing on the experience of the actors involved in governance, which often includes those affected by the collective problems, or it can be incorporated as proven expertise provided by outsiders. Expert knowledge is particularly important for governance if the actors involved have not yet made it clear how their different and sometimes conflicting interests relate to each other. This is particularly evident, for example, in the principles Ostrom (2005) has suggested for the appropriate design of the governance of collective goods. The character of collective goods becomes particularly evident with many natural, renewable resources, which are threatened by overexploitation, that is, when actors prioritize the pursuit 
of individual profit over collective gains (Hardin, 1968). Knowledge about the properties of these resources, the periods of their renewal, their location in space, and their accessibility for exploitation are a prerequisite of resource governance. In addition, knowledge about the constellation of actors involved in the use of the resources as well as knowledge about the possibilities to monitor and sanction those who direct their behavior against the collective gain relevance. It helps actors to assign roles and responsibilities in governance processes. Knowing the institutional context (Glückler, 2020; Glückler, Punstein, Wuttke, \& Kirchner, 2020) allows actors to establish governance practices that are coherent or complementary with legitimate mutual expectations (Boyer, 2005). Institutions provide and impart knowledge for governance in their own specific way.

The authors of the book's first part illustrate and discuss the extent to which knowledge is a prerequisite for governance. Questions of the sources and the quality of available knowledge inputs pave the way to assess the appropriateness of different types of knowledge for a specific governance case. Not all knowledge is suitable for usage and valorization in governance. Knowledge for governance is often subject to doubts on the part of certain participating actors, a circumstance that must be taken seriously in the design of a governance process. In the five chapters forming this part of the book, the contributors tackle four important yet empirically contested ways in which knowledge becomes a crucial resource and prerequisite for governance: (i) the availability and control of knowledge for governance (see Chap. 2 by Lipo, Mischen, and Hunt), (ii) the manipulation of the content and interpretation of knowledge (see Chap. 3 by Scott), (iii) the varying relevance of different types of knowledge for governance (see Chap. 4 by Stehr and Chap. 5 by Renn), and (iv) the differences in legitimacy of those who know (see Chap. 6 by Bell and Hindmoor). These five sets of contributors deal with these aspects from different perspectives of disciplinary governance research.

In the second chapter, Carl P. Lipo, Pamela Mischen, and Terry L. Hunt emphasize the importance of having sophisticated knowledge about a resource's availability and the characteristics of its place of origin in order to be able to manage it sustainably. They use the example of prehistoric Rapa Nui to demonstrate how humankind wrestles place dependently over issues of governance by developing capabilities to survive on an isolated island with scarce resources. Ever since their arrival on Easter Island (now belonging to Chile), the Rapa Nui have been confronted with uncertainties about global climate change and fluctuating resource stores. Lipo, Mischen, and Hunt argue that whereas the case of prehistoric Rapa Nui has often been treated as a warning about human-caused ecological catastrophe, new archaeological and multidisciplinary findings indicate that land use on Easter Island had been sustainable during its prehistory until the Europeans arrived. In retrospect, the governance practices collectively applied at Easter Island appear to have been highly innovative and locally appropriate. These findings point to the potential of alternative action models and new governance structures. The authors further show that scientists who analyze governance cases must constantly reassess their own knowledge. 
Actors utilize different techniques to control knowledge for governance. Discursive knowledge (van Dijk, 2014), for example, influences the contents and contested negotiations in governance processes. Knowledge can be manipulated with certain modes of communication. Rule-based routines (Becker \& Knudsen, 2005; Ostrom, 2000) are a way of collectively preserving knowledge and facilitating decision making in governance. However, they must first often be discovered and adjusted to each other. In the third chapter, Michael Scott analyzes how knowledge as well as particular opinions can be specifically controlled in governance processes in order to reach agreement and influence results. Drawing on empirical cases of coastal property developments in South Australia, he investigates how key actors in land-use governance-such as developers, planners, politicians, and scientists-reflexively deploy "techniques of neutralization" to deflect critiques and manage opposition to contentious new developments. Scott explores how actors use these techniques to draw on particular spatial metaphors and images to suggest that, somewhat ironically, a tacit metatechnique is to neutralize the projected environmental risks to coastal space through narratives of time. Awareness of the usage of these techniques is a valuable knowledge input for governance on its own.

The manner in which knowledge is made relevant, structured, communicated, and exploited is shaped by its source. The contributors of the two subsequent chapters focus on the way in which governance processes become both a competition among ideas and a contest regarding what may count as legitimate. In the book's fourth chapter, Nico Stehr highlights how important scientific knowledge is a prerequisite for effective climate policy. He critically illustrates how local, regional, and national actions related to climate deliberately ignore the expertise of scientists and unacceptably limit the effectiveness of climate policy. On this basis, he diagnoses the failure of large social organizations to respond in a timely fashion to the progress of climate change knowledge, an observation that he denotes as "inconvenient institutions." The sense of political ineffectiveness felt especially among climate scientists provokes a strong disenchantment with democratic governance. As a result, he proposes that political action based on principles of democratic governance be abandoned. Stehr concludes that such a view is mistaken and calls instead for better democratic processes.

In a similar direction and with regard to risk governance, Ortwin Renn argues in the fifth chapter that scientific knowledge does not provide answers to everything. Instead, in many cases it is ambivalent and uncertain and cannot grasp every aspect of a collective action problem at once. In his conceptual contribution, he argues that risk governance is above all about organizing communication processes so that constant knowledge inputs can feed and reproduce an ongoing learning process. Renn introduces the concept of risk governance developed by the International Risk Governance Council in Geneva, which provides guidance for constructing comprehensive assessment and management strategies to cope with risk. It integrates three types of scientific input: classic, curiosity-driven research; strategic, goal-oriented research; and catalytic, process-related investigations. He demonstrates how these three knowledge pools can help risk assessors and managers to better understand complex risk situations. In many governance cases, expert and scientific knowledge 
seem to have interpretive sovereignty. The authors of recent studies illustrate, however, that governance failure is likely if social stakeholders, who are invited to participate in governance processes alongside experts from scientific fields, find that their practical knowledge is ignored or undervalued (e.g., in cases where their experience is affected by unsolved collective goods problems; cf. also Chap. 18 by Herrigel in the third part of this book).

For some collective action problems, (scientific) knowledge does not exist in the first place, either because the collective problem represents a new phenomenon or because it is one that only evolves progressively. In this case, actors must rely on experiential knowledge. In Chap. 6, Stephen Bell and Andrew Hindmoor discuss how failures incurred by previous decisions are an important source of learning in governance that can make it possible to improve the coordination of collective action. Drawing on the phenomenon of systemic risk in financial markets that occurs when financial actors collectively (if inadvertently) bring on a major financial crisis through the withholding of credit and asset fire sales, they focus on coordinated efforts to prevent such calamities. Using the European debt crisis as an empirical example, they show that where appropriate knowledge and governance arrangements can be put in place, collective action may be arranged to help prevent the uncertain crystallization of systemic risk.

The authors of the five chapters in the first part of this book show not only how important knowledge is as a prerequisite for governance; they also demonstrate that knowledge, and its interpretation, is not free of mistakes. Actors often purposively manipulate or unintentionally modify knowledge by discourse and normative intervention.

\section{How Knowledge Drives the Effectiveness of Governance}

Due to the context-specificity of knowledge and the many alternatives for organizing governance over time, similar and comparable knowledge inputs can often yield different results. The second part of this book, therefore, contains a series of five chapters that, despite differences in their research questions, all help reveal how knowledge drives the very efficacy of governance. These chapters' authors focus on the way in which the level of knowledge and expertise effects governance outcomes (see Chap. 7 by Avellaneda, Bello-Gómez, and Olvera). Contributors variously focus on the type of knowledge, such as restriction on only one domain (see Chap. 8 by Handke); the adaptation of knowledge to local contexts (see Chap. 9 by KnoxHayes, Hayes, and Hughes); the limitations of knowledge in breaking up ineffective governance (see Chap. 10 by Pohlmann and Valarini); and the way in which knowledge of governance structures can improve legitimacy relations among governance actors (see Chap. 11 by Glückler).

In Chap. 7, Claudia N. Avellaneda, Ricardo Andrés Bello-Gómez, and Johabed G. Olvera assess the impact of differential levels of knowledge on governance. To this end, they look at the local level of communal politics in Mexico and 
Colombia, where recent efforts to decentralize responsibilities have produced diverse results. Empirically, they are interested in how mayors' wide range of technical training (codified knowledge) and experience (uncodified knowledge) steer official action towards locally improved development. Depending on the context, decision makers' specialist knowledge and experience can have very different effects. Indeed, sometimes their actions make no difference whatsoever. With their findings, they caution governance researchers from generalizing results. What drives performance in one country may not have the same explanatory power in another country.

In Chap. 8, Michael Handke looks at how the use of knowledge from just one rigid domain can blind actors to possible new solutions for solving collective action dilemmas. He argues that unilaterally quantified knowledge about forest fire risks in Chile fails to capture the spatiotemporal diversity of this very context-specific risk. Whereas some big private companies consider hierarchical risk control and making use of the insurance market to be cost efficient, small forest owners in Chile do not have the same access to this form of risk management due to its high demand on technical knowledge and organizational competences. On the regional scale, where actors perceive forest fires as a collective problem, this leads to negative external effects and social conflicts. Handke assesses the strengths and weaknesses of interacting hierarchical and market forms of risk management and pleads for a geographical approach to risk governance. He demonstrates that current risk management practices explicitly decontextualize detailed geographical knowledge of forest fire risks. Localized knowledge of the causes and effects of forest fire risks thus gets lost in the process.

In Chap. 9, Janelle Knox-Hayes, Jarrod Hayes and Erik-Logan Hughes suggest that knowledge inputs in governance must be adapted to local regulatory and institutional conditions, questioning the doctrine of placeless perfect markets. Empirically, they illustrate how markets have to be contextually designed in order to be effective. Using the example of markets for $\mathrm{CO} 2$ certificates that are established around the world and that the Kyoto Protocol incentivizes as the dominant mechanism for mitigating climate change, they analyze how textbook knowledge about the functioning of markets needs to be given context-specific value. They conclude that international efforts to promulgate market mechanisms run up against local cultures of markets that shape economic practices and knowledge to different degrees. Markets are enacted via political processes entailing different amounts of public, stakeholder, and expert involvement and varying levels of trust in technocratic government agencies, private firms, and scientific authority. Market cultures highlight issues at the interface of political and economic governance, including issues of citizen, state, and industry participation, and the materiality of economic and financial productivity.

In some circumstances, however, any governance effort to solve problems of collective action may fail completely. Long-established practices of coordinating interests in society can turn out to be institutionally encrusted so that new impulses for governance remain ineffective. In Chap. 10, Markus Pohlmann and Elizangela Valarini analyze anticorruption governance in Brazil. By carrying out content 
analyses of court files on corporate crime and the involvement of the public sector, they show how systemic institutional encrustation undermines changes in governance practice. Even with new knowledge for governance-in this case the implementation of rigid international standards for good governance - corruption persists, with far-reaching consequences for Brazil's development.

Finally, knowledge about governance itself helps actors assess, improve, or adapt governance models in a particular context. If governance refers to the purposive coordination of collective action between interdependent stakeholders, then methods of social network analysis can be helpful to map and analyze the structure of social interactions that reflect the "lived" practices of coordination and decision making. At this intersection, governance theory and network theory offer space for crossfertilization (Glückler, Lazega, \& Hammer, 2017). Not only do social network researchers offer useful methods to identify the patterns of relations among sets of actors; they also provide valuable theories on how specific positions within a network, and how specific formations of whole networks, facilitate certain social outcomes such as innovation, social support, and solidarity or other types of problem solving (e.g., Kilduff \& Tsai, 2003; Knoke, 2012). In Chap. 11, Johannes Glückler goes beyond viewing networks as a governance mode (Podolny \& Page, 1998; Williamson, 1991) to examine how the lived practice of governance in a network actually conveys legitimate and acceptable collective coordination. $\mathrm{He}$ advances the concept of lateral network governance in the empirical context of organized networks, in which firms pool resources and join their interests in the pursuit of common goals. To solve the puzzle of how independent equals commit themselves to coordinating their actions, Glückler proposes overcoming the traditional dualism between formal and informal mechanisms of governance. He conceives lateral network governance as a structure for the legitimate delegation of decision making and develops a social network analytic approach to assessing the relational distribution of legitimacy, utilizing two case studies of interfirm network organizations to illustrate the extent to which the actual legitimacy distribution diverges from formal governance authority.

\section{How Governance Affects Learning and Innovation}

In part three of this volume, the contributors invert the perspective given in the previous chapters and reveal how governance also affects the creation and adoption of knowledge. In five chapters, each from a different angle, they show that learning in governance takes time and needs to be actively organized (see Chap. 12 by Niemeyer), that it requires a minimum degree of flexibility to allow learning from mistakes during the organization of the process (see Chap. 13 by Schultz, West, and Florêncio), and that the outcome of learning processes depends in part on whether organizations have the capacity to act under fragmented responsibilities (see Chap. 14 by Raab, Kenis, Kraaij-Dirkzwager, and Timen) or are able to link collective learning to institutional collective action (see Chap. 15 by Kim, Swann, and 
Feiock). In addition, fragmentation seems to facilitate learning outcomes. Learning also occurs in the course of the renegotiation of power, which may in turn change the meaning of knowledge (see Chap. 16 by Hayter and Clapp).

Contemporary collective challenges, such as global environmental change, cannot be dealt with by drawing on the knowledge of one generation alone. In Chap. 12, Simon Niemeyer argues that in order to overcome global dynamics, individuals must adopt an open and humble deliberative attitude to be able to accelerate the assessment of uncertain and complex collective issues. He draws evidence from small-scale settings characterized by deliberative minipublics, in other words, organized communication processes at the microlevel of governance. In group meetings and organized face-to-face situations, actors incrementally pass on knowledge and views on climate change to other governance participants. Perceptions change depending on the group affiliation. The observed mechanisms can be "scaled up" to inform possibilities for wider reform of the processes governing the uptake and use of knowledge.

Flexibility in the organization and coordination of governance stakeholders can accelerate the learning process. In Chap. 13, Lisen Schultz, Simon West, and Cláudia Florêncio argue that actors in learning situations must be allowed to make mistakes in order to adapt to heterogeneous contexts. They call this adaptive governance. Focusing on the people, practices, and politics involved with adaptive governance in the Global South, they use the administration of the Kruger to Canyons Biosphere Region in South Africa to show that the practices for generating knowledge, sharing information, collaborating, and responding to change emerge as players navigate tensions between diverse values, norms, and routines. Focusing on the way that people, practices, and politics monitor and prevent poaching highlights how adaptive governance is situated and involves agency, meaning, and creativity. In this respect, successful governance often requires changes to existing institutional structures: "The governance concept points to the creation of a structure or an order which cannot be externally imposed but is the result of the interaction of a multiplicity of governing and each other influencing actors" (Kooiman \& van Vliet, 1993, p. 64).

Although actors involved in governance orient their actions towards a common goal, this does not rule out the possibility that their interests diverge. The manner in which individual interests are reflected in governance can influence the effectiveness of learning processes. In Chap. 14, Jörg Raab, Patrick Kenis, Marleen KraaijDirkzwager, and Aura Timen examine organizations' capacity to act under fragmented responsibility. They focus on the risk of epidemic catastrophes and demonstrate that involved actors perceive knowledge and timely information about the spread of viruses differently, ultimately hindering interorganizational learning. They demonstrate how the organizational network governance approach can generate information necessary for specific organizational players to limit the transmission of a virus and its impact.

In contrast to this, Serena Y. Kim, William L. Swann, and Richard C. Feiock demonstrate how the capacity for organizational learning can be collectively supported even in situations of conflicting interests. In Chap. 15, they argue that greater 
knowledge about collaboration and more information about partners enables actors to better deal with collaboration problems, heterogeneous preferences, and weak institutions for collaboration. In their conceptual contribution, they posit three pathways that link collective learning to institutional collective action and put forward propositions as to how such learning can reduce collective action dilemmas and enhance future collaboration. In the first path, collaborative choices and outcomes affect collective learning. In the second path, collective learning directly mitigates collaboration risks and in turn alters the choice of integrative mechanism. In the third path, collective learning moderates the relation between the collaboration situation and risks - that is, collective learning has greater impact in situations characterized by highly fragmented, specialized, and multifaceted contexts than in low-complexity situations.

The reflexive relationship of knowledge and governance is particularly evident in those cases in which knowledge enters both as an input to governance and evolves as an improved outcome in the course of the governance process. In Chap. 16, Roger Hayter and Alex Clapp look at conflicts over forest and timber resources in British Columbia, analyzing how stakeholders with different geographical presence and influence continuously renegotiate the societally accepted values of these resources. Negotiations are part of the governance process and lead to a remapping of the relationship between economy and society. Hayter and Clapp interpret remapping in British Columbia as an attempt to transform the commodity-driven and shareholderoriented forest management associated with Fordism into more locally diverse forms of governance as part of a post-Fordist, techno-economic paradigm. This remapping goes hand in hand with institutional thickening, in other words, a process to bring together opposing parties to exchange views and develop respectful relationships and to implement new forms of governance. Stakeholder remapping is not just a practice, but also a result of governance. The authors of this book's last three contributions all place industrial innovation at the center of their analysis as the result of planned governance efforts. In Chap. 17, Christian Binz and Bernhard Truffer suggest that technological innovation increasingly depends on multiscalar actor networks and institutions. They criticize perspectives on innovation that bracket the problem of scale and focus exclusively on discrete spatial units (regions or countries) that both act as agents structuring innovation governance and serve effectively as containers providing institutional conditions for success. Instead, they elaborate on the recently formulated Global Innovation Systems approach, which enables researchers to capture the emergence of system resources across spatial scales. With this framework, Binz and Truffer emphasize that beyond the focus on knowledge generation, a better understanding of "valuation" processes is necessary to guide governance structures for generating new technologies and products.

Complementarily to this, Gary Herrigel in Chap. 18 explores a particular form of MNC governance practices within interlinked global production clusters producing identical end products in different markets. Because diffusion of these clusters is accompanied by significant operational uncertainty, Herrigel claims that many emergent MNC governance practices have an experimentalist character. Stakeholder inclusive teams at the center provisionally set product standards and performance 
metrics that are then appropriately and transparently modified by local teams, often resulting, through formal justification procedures, in the modification of the initial central standards and metrics. Recursivity in knowledge flow and practice diffuses learning and innovation throughout the MNC. Movement towards experimentalist governance in MNCs exists but is neither seamless nor uncomplicated. Three sorts of obstacles are most common-hierarchical insulation, stakeholder exclusion, and inadequate empowerment resources for participants. These obstacles exist not only ex ante, as firms attempt to construct formal experimentalist systems and implement them throughout their global operations; they also are continually regenerated by the experimentalist dynamics themselves. In order to prevent such obstacles from paralyzing the global process of recursive learning, MNCs are developing an array of destabilization mechanisms that systematically undermine insulation and exclusion strategies within the global firm and reconstitute the deliberative experimentalist learning process.

In the final chapter of this volume, Nebahat Tokatli explores the innovation processes in the flat-glass industry, questioning the extent to which interfirm networks facilitate innovation over a long period of time. Ultimately, Toklati argues that networks lose influence on innovations in the course of the evolution of an industry. When it comes to the secondary processing of flat glass, the assets of innovation are now much more dispersed (locally and globally) than they were before. In addition, contexts in which individual products and processes draw on multiple internal and external sources of technology are now becoming more and more pervasive in the secondary processing of glass.

\section{Governance and Geography}

Governance fulfills tasks in a wide variety of fields and across a variety of spatial scales. One of this book's key arguments is that governance cannot be conceived as a placeless category (Glückler, Rehner, \& Handke, 2019). Geography and space are important in at least two respects, again reflecting the logic of reflexivity: First, space is a context for governance. Material conditions as well as social relations and institutions are often place-specific and thus pose particular conditions and require specific adaptation for governance to be effective. A seemingly universal, a-spatial governance blueprint will yield differential effect in different places. Therefore, we claim that governance theory is unlikely to yield general solutions that convey optimal outcomes at any place and any time. Second, and conversely, space is an object of governance, and governance creates spaces. Governance has implications for the geographical boundedness (jurisdiction) as well as the quality of opportunities and constraints of actors. Governance may also generate geographical spillover effects on other actors not directly involved in the process, both locally and in other places (e.g., climate change, financial crises, forest fire risk, or environmental pollution). The relation to space is not only about locality but also about relations between regions and across scales. For instance, governance can resolve local dependencies 
and combine them with action in other places, as in a local environmental movement's cooperation with a global NGO, in order to develop greater impact on the ground.

The first relationship between governance and space becomes clear simply by the fact that actors, collective action, and collective problems are situated and bounded in geographical contexts. Governance actors must respond to the specific physical, social, political, and institutional contexts in particular places in order to address conflicts of interest and collective action problems for a common good. The traditions of governance research differ fundamentally in the way in which they conceive the actors and the roles ascribed to them (Knill \& Lehmkuhl, 2002; Peters, 2014). Governance can be driven forward by self-organizing, autonomous stakeholders (Gardner, Ostrom, \& Walker, 1992; Rhodes, 1996) who coordinate their collective actions in a targeted manner, especially at the local or regional level, where interactions are particularly visible and manageable. Governance is also about differently organizing the relations between the state and civic actors (Bell \& Hindmoor, 2009). The role of states in governance is no longer limited to regulation in the legal territorial area that they supervise. It ranges from direct alliances with multiple stakeholders (Osborne, 2000) to its action as the "shadow of the hierarchy" (Héritier \& Lehmkuhl, 2008). Governance is acknowledged to create its own institutional space.

Several contributors to this volume take geographical location as the starting point for their governance analysis. They either refer to problems in dealing with the accessibility and exploitability of spatially distributed collective resources, such as agricultural land in the confined space of Easter Island (see Chap. 2 by Lipo et al.), ${ }^{1}$ or they highlight the spatial dimensions of risks, as in the case of forest fires in Chile, which threaten larger groups in society (see Chap. 8 by Handke). ${ }^{2}$ Space is a suitable category for locating collective problems, even where many problems transgress the conventional distinction between local and global. Researchers use the geography of governance to not only look at the diversity and relations between places, but also at the interdependencies across spatial scales. Often, governance cannot be restricted to just one scale but requires the analysis of several scales and of the interrelations across them. Several contributors to our book, for example, address the challenges of mastering global climate change in context-specific ways (see Chap. 9 by Knox-Hayes et al., Chap. 12 by Niemeyer, and Chap. 4 by Stehr).

Other contributors elaborate on the second relationship between governance and geography, how collective interactions make and transform geography. Space is the place in and through which knowledge is generated, to which certain knowledge is bound, and from which it is intentionally exploited. Situated action and spatial social relationships influence the functionality of governance (see Chap. 12 by Niemeyer and Chap. 10 by Pohlmann and Valarini). Individual actors and their

\footnotetext{
${ }^{1}$ Also forest landscapes and timber resources in Canada (see Chap. 16 by Hayter and Clapp).

${ }^{2}$ Also the spread of infectious viruses (see Chap. 14 by Raab et al.) or coastal regions affected by rising sea levels in Australia (see Chap. 3 by Scott).
} 
levels of impact can be taken as the starting point for a deeper analysis. Influences on their decisions and actions, however, come from many other dimensions that governance research must take into account. Several authors analyze how localized collective coordination problems affect innovations for global markets and recognize the disadvantages of location-bound and one-sided hierarchical or marketbased forms of governance (see Chap. 17 by Binz and Truffer, Chap. 18 by Herrigel, and Chap. 19 by Tokatli).

A comparative empirical approach on governance research creates new analytical opportunities. Researchers should put particular emphasis on analyzing governance cases to assess the utility of and fit with fundamental governance models, and on designing and adapting appropriate contextual solutions (Glückler et al., 2019). In addition, by constant collection and comparison of governance cases, researchers are sensitized to the experience that general models perform differently in different situations, that similar governance challenges can be met with different models, and that well-designed governance processes can fail or have unintended consequences.

\section{Conclusion and Questions Ahead}

Governance emerged as a scholarly preoccupation, historically, as the post-WorldWar-II global order began to fall into crisis in the 1990s. Bureaucratic mechanisms deployed by the state (planning) and by corporations (managerial hierarchies/vertical integration) were revealed to be overly rigid and unsustainable. Global competition and pressures for nearly permanent innovation as well as natural hazards and growing environmental impact of social and economic activities together destabilized roles, industries, and regions, while simultaneously placing a high value on flexibility. Traditional top-down command and control bureaucracy was simply overwhelmed by the new conditions. At the same time, despite great ideological enthusiasm, it quickly became clear that market mechanisms alone were nearly always incapable of maintaining stable and equitable coordination. Competition frequently broke down as players undercut one another to improve (or maintain) their position, whereas social and environmental collateral damage from market action generated pushback from many affected quarters. The result has been pervasive exploration of modes of coordination that subsume, abandon, and sometimes transcend both bureaucratic and market forms of social ordering. The authors of this volume demonstrate quite clearly how governance arrangements today can come in a remarkable array of guises and in ways that transgress traditional, formerly very reliable, analytical oppositions between public and private, bureaucracy and market, national and transnational, political and economic — and so on.

Although we do not pretend to present a comprehensive overview of governance in this volume, the essays here do show how plastic and wide ranging the problem of governance has become. The chapters' authors discuss a remarkably diverse range of governance concepts and techniques. These concepts include corporate 
governance (see Chap. 17 by Binz and Truffer), network governance (see Chap. 11 by Glückler), adaptive governance (see Chap. 13 by Schultz et al.), deliberative governance (see Chap. 12 by Niemeyer), risk governance (see Chap. 6 by Bell and Hindmoore, Chap. 8 by Handke, and Chap. 5 by Renn), and environmental governance (see Chap. 4 by Stehr, Chap. 3 by Scott, and Chap. 9 by Knox-Hayes et al.), governance by experimentalism (see Chap. 18 by Herrigel) as well as good governance (see Chap. 7 by Avellaneda et al. and Chap. 10 by Pohlman and Valarini). In the governance cases presented, civil society (see Chap. 16 by Hayter and Clapp and Chap. 2 by Lipo et al.), the state (see Chap. 15 by Kim et al. and Chap. 14 by Raab et al.) and the private sector (see Chap. 18 by Herrigel and Chap. 19 by Tokatli) perform different roles with different levels of divisions of labor.

Very broadly, the essays in this volume permit a number of theoretical and loosely empirical observations that can be explored in future research. To start with, its contributors indicate that governance can be profitably arranged along two dimensions. First, governance refers to efforts on the part of interdependent actors (however constituted) to resolve social, economic, or political problems that have been either jointly defined or commonly agreed upon. Second, space and knowledge are two crucial parameters for governance. Knowledge gives content to and drives practice, whereas all forms of action both unfold in and construct space. In future, researchers need to explore the relationship between power and knowledge within governance practices. In particular, to what degree is "jointness" in the identification of coordination difficulties compatible with power asymmetries? Can collaborative governance, dependent upon input from affected stakeholders, be imposed from above, either by states or corporate management (say, in the governance of their supply chains)? To what degree are the more traditional governance mechanisms of hierarchy and market still salient in contemporary governance arrangements and coordination practices?

Along the same lines, the essays here not only serve as testament to the centrality of knowledge in contemporary economic and social life, but also reveal considerable ambiguity about the scope and limits of knowledge for governance. How much knowledge is enough? Can coordination be sustained while important knowledge carrying players are excluded from the design and practice of governance arrangements? What are the limits of inclusivity for the identification of joint problems and goals for associated actors? More broadly, must researchers explore the extent to which governance arrangements can exclude forms of knowledge from entering into participant governance deliberations? How can actors make governance practices more robust and sustainable, capable of accommodating a broad range of challenges and innovations? Similar questions can be posed about space: How fungible are the spatial dimensions of governance? Researchers must more thoroughly examine the extent to which space acts as a constraint on the construction of governance arrangements, and the extent to which the search for stable coordination recasts social interaction spatially.

Finally, two other aspects of the governance discussion in this volume emerge as crucial for future work. First, uncertainty, driven by competition, on-going organizational and technological innovation and collateral political and social 
recomposition, is a crucial environmental condition for understanding contemporary governance efforts. To what extent do those making governance arrangements seek to accommodate themselves to this uncertainty? That is, how are practices arranged in such a way that continuous innovation and "dynamic capabilities" (Teece et al., 1997) are the outcome of governance? Alternatively, is it possible for interconnected players to construct governance arrangements that insulate them from uncertainty? Secondly, reflexivity, in other words, the organized practice of observing the outcomes of coordinated action and adjusting rules and roles in social coordination in light of those observations, is an emergent and crucially important area for analytical attention. Crises come when old arrangements for governing coordination no longer function and alternative forms of coordination have yet to be created. What kinds of creative search and recombinatory processes do actors deploy to overcome crisis and reestablish stable governance? Can such search and learning processes be organized in a systematic manner, such that disruptive and paralyzing crises can be avoided? These and other questions indicate some of the directions for future research in a promising and growing field of transdisciplinary scholarship whose participants aim to help solve collective action dilemmas in environmental, social, political, and economic contexts.

\section{References}

Amin, A., \& Cohendet, P. (2004). Architectures of knowledge: Firms, capabilities, and communities. Oxford, UK: Oxford University Press. https://doi.org/10.1093/acprof: oso/9780199253326.001.0001

Ansell, C., \& Torfing, J. (2016). Handbook on theories of governance. Cheltenham: Edward Elgar.

Avellaneda, C. N., Bello-Gómez, R. A., \& Olvera, J. G. (2020). Explaining subnational governance: The role of governors' codified and uncodified knowledge. In J. Glückler, G. Herrigel, \& M. Handke (Eds.), Knowledge for governance (pp. 131-159). Knowledge and Space: Vol. 15. Cham: Springer. https://doi.org/10.1007/978-3-030-47150-7_7

Bache, I., \& Flinders, M. (2004). Multi-level governance. Oxford, UK: Oxford University Press. https://doi.org/10.1093/0199259259.001.0001

Barley, S. R., \& Tolbert, P. S. (1997). Institutionalization and structuration: Studying the links between action and institution. Organization Studies, 18, 93-117. https://doi. org/10.1177/017084069701800106

Bathelt, H., \& Glückler, J. (2011). The relational economy: Geographies of knowing and learning. Oxford, UK: Oxford University Press. https://doi.org/10.1093/acprof:os obl/9780199587384.001.0001

Becker, M. C., \& Knudsen, T. (2005). The role of routines in reducing pervasive uncertainty. Journal of Business Research, 58, 746-757. https://doi.org/10.1016/j.jbusres.2003.10.003

Bell, S., \& Hindmoor, A. (2009). Rethinking governance: The centrality of the state in modern society. Cambridge, UK: Cambridge University Press. https://doi.org/10.1017/ CBO9780511814617

Bell, S., \& Hindmoor, A. (2020). Knowledge and governance: Can systemic risk in financial markets be managed? The case of the Euro crisis. In J. Glückler, G. Herrigel, \& M. Handke (Eds.), Knowledge for governance (pp. 113-128). Knowledge and Space: Vol. 15. Cham: Springer. https://doi.org/10.1007/978-3-030-47150-7_6 
Benz, A., \& Dose, N. (2010). Governance-Regieren in komplexen Regelsystemen: Eine Einführung [Governance-Governing in complex control systems: An introduction]. Wiesbaden: VS Verlag für Sozialwissenschaften.

Bevir, M. (2010). The SAGE handbook of governance. London: SAGE.

Binz, C., \& Truffer, B. (2020). The governance of global innovation systems: Putting knowledge in context. In J. Glückler, G. Herrigel, \& M. Handke (Eds.), Knowledge for governance (pp. 397-414). Knowledge and Space: Vol. 15. Cham: Springer. https://doi. org/10.1007/978-3-030-47150-7_17

Borgatti, S. P., \& Cross, R. (2003). A relational view of information seeking and learning in social networks. Management Science, 49, 432-445. https://doi.org/10.1287/mnsc.49.4.432.14428

Boyer, R. (2005). How and why capitalisms differ. Economy and Society, 34, 509-557. https://doi. org/10.1080/03085140500277070

Chhotray, V., \& Stoker, G. (2009). Governance theory and practice: A cross-disciplinary approach. Houndsmill: Palgrave Macmillan. https://doi.org/10.1057/9780230583344

Fleck, L. (1935). Entstehung und Entwicklung einer wissenschaftlichen Tatsache: Einführung in die Lehre vom Denkstil und Denkkollectiv [Origin and development of a scientific fact: Introduction into the doctrine of thinking style and thought collective]. Basel: B. Schwabe.

Gardner, R., Ostrom, E., \& Walker, J. (1992). Covenants with and without a sword: Self-governance is possible. American Political Science Review, 86, 404-417. https://doi.org/10.2307/1964229

Glückler, J. (2020). Institutional context and place-based policy: The case of Coventry \& Warwickshire. Growth \& Change, 51, 234-255. https://doi.org/10.1111/GROW.12362

Glückler, J. (2020). Lateral network governance. In J. Glückler, G. Herrigel, \& M. Handke (Eds.), Knowledge for governance (pp. 243-265). Knowledge and Space: Vol. 15. Cham: Springer. https://doi.org/10.1007/978-3-030-47150-7_11

Glückler, J., Meusburger, P., \& El Meskioui, M. (2013). Introduction: Knowledge and the geography of the economy. In P. Meusburger, J. Glückler, \& M. El Meskioui (Eds.), Knowledge and the economy (pp. 3-14). Knowledge and Space: Vol. 5. Dordrecht: Springer. https://doi. org/10.1007/978-94-007-6131-5_1

Glückler, J., Lazega, E., \& Hammer, I. (2017). Knowledge and networks. Knowledge and Space: Vol. 11. Cham: Springer. https://doi.org/10.1007/978-3-319-45023-0

Glückler, J., \& Lenz, R. (2018). Drift and morphosis in institutional change: Evidence from the 'Walz' and public tendering in Germany. In J. Glückler, R. Suddaby, \& R. Lenz (Eds.), Knowledge and institutions (pp. 111-134). Knowledge and Space: Vol. 13. Cham: Springer. https://doi.org/10.1007/978-3-319-75328-7_6

Glückler, J., Punstein, A. M., Wuttke, C., \& Kirchner, P. (2020). The 'hourglass' model: An institutional morphology of rural industrialism in Baden-Württemberg. European Planning Studies, 28, 1554-1574. https://doi.org/10.1080/09654313.2019.1693981

Glückler, J., Rehner, J., \& Handke, M. (2019). Gobernanza, redes y territorio [Governance, networks, and territory]. Revista de Geografía Norte Grande, 74, 5-20. http://dx.doi.org/10.4067/ S0718-34022019000300005

Glückler, J., Suddaby, R., \& Lenz, R. (2018). Knowledge and institutions. Knowledge and Space: Vol. 13. Cham: Springer. https://doi.org/10.1007/978-3-319-75328-7

Handke, M. (2020). The (de-)contextualization of geographical knowledge in forest-fire risk management in Chile as a challenge for governance. In J. Glückler, G. Herrigel, \& M. Handke (Eds.), Knowledge for governance (pp. 161-191). Knowledge and Space: Vol. 15. Cham: Springer. https://doi.org/10.1007/978-3-030-47150-7_8

Hardin, G. (1968). The tragedy of the commons. Science, 162, 1243-1248. https://doi.org/10.1126/ science.162.3859.1243

Hayter, R., \& Clapp, A. (2020). The remapping of forest governance: From shareholder to stakeholder. In J. Glückler, G. Herrigel, \& M. Handke (Eds.), Knowledge for governance (pp. 375-395). Knowledge and Space: Vol. 15. Cham: Springer. https://doi. org/10.1007/978-3-030-47150-7_16 
Héritier, A., \& Lehmkuhl, D. (2008). Introduction: The shadow of hierarchy and new modes of governance. Journal of Public Policy, 28, 1-17. https://doi.org/10.1017/S0143814X08000755

Herrigel, G. (2010). Manufacturing possibilities: Creative action and industrial recomposition in the USA, Germany and Japan. Oxford, UK: Oxford University Press. https://doi.org/10.1093/ acprof:oso/9780199557738.001.0001

Herrigel, G. (2020). Experimentalist systems in manufacturing multinationals: Recursivity and continuous learning through destabilization. In J. Glückler, G. Herrigel, \& M. Handke (Eds.), Knowledge for governance (pp. 415-439). Knowledge and Space: Vol. 15. Cham: Springer. https://doi.org/10.1007/978-3-030-47150-7_18

Herrigel, G., Wittke, V., \& Voskamp, U. (2013). The process of Chinese manufacturing upgrading: Learning in supply chains and through the dynamics of FDI. Global Strategy Journal, 3, 109-125. https://doi.org/10.1111/j.2042-5805.2012.01046.x

Hess, C., \& Ostrom, E. (2007). Understanding knowledge as a commons: From theory to practice. Cambridge, MA: MIT Press.

Hodgson, G. M. (2006). What are institutions? Journal of Economic Issues, 40, 1-25. https://doi. org/10.1080/00213624.2006.11506879

Jessop, B. (1998).The rise of governance and the risks of failure: The case of economic development. International Social Science Journal, 50, 29-45. https://doi.org/10.1111/1468-2451.00107

Keast, R. (2016). Network governance. In C. Ansell \& J. Torfing (Eds.), Handbook on theories of governance (pp. 442-453). Cheltenham: Edward Elgar.

Kilduff, M., \& Tsai, W. (2003). Social networks and organizations. London: SAGE.

Kim, S. Y., Swann, W. L., \& Feiock, R. C. (2020). Collective learning and institutional collective action in fragmented governance. In J. Glückler, G. Herrigel, \& M. Handke (Eds.), Knowledge for governance (pp. 351-373). Knowledge and Space: Vol. 15. Cham: Springer. https://doi. org/10.1007/978-3-030-47150-7_15

Knill, C., \& Lehmkuhl, D. (2002). Private actors and the state: Internationalization and changing patterns of governance. Governance: An International Journal of Policy, Administration, and Institutions, 15, 41-63. https://doi.org/10.1111/1468-0491.00179

Knoke, D. (2012). Economic networks. Cambridge: Polity.

Knox-Hayes, J., Hayes, J., \& Hughes, E.-L. (2020). Carbon markets, values, and modes of governance. In J. Glückler, G. Herrigel, \& M. Handke (Eds.), Knowledge for governance (pp. 193-224). Knowledge and Space: Vol. 15. Cham: Springer. https://doi. org/10.1007/978-3-030-47150-7_9

Kooiman, J. (1993). Governance and governability: Using complexity, dynamics and diversity. In J. Kooiman (Ed.), Modern governance: New government-society interactions (pp. 35-50). London: SAGE.

Kooiman, J., \& van Vliet, M. (1993). Governance and public management. In K. Eliassen \& J. Kooiman (Eds.), Managing public organizations: Lessons from contemporary European experience (pp. 58-72). London: SAGE.

Lawrence, T. B., Leca, B., \& Zilber, T. B. (2013). Institutional work: Current research, new directions and overlooked issues. Organization Studies, 34, 1023-1033. https://doi. org/10.1177/0170840613495305

Levi-Faur, D. (2012). The Oxford handbook of governance. Oxford, UK: Oxford University Press. https://doi.org/10.1093/oxfordhb/9780199560530.001.0001

Lipo, C. P., Mischen, P., \& Hunt, T. L. (2020). Lessons from Rapa Nui (Easter Island, Chile) for governance in conditions of environmental uncertainty. In J. Glückler, G. Herrigel, \& M. Handke (Eds.), Knowledge for governance (pp. 25-49). Knowledge and Space: Vol. 15. Cham: Springer. https://doi.org/10.1007/978-3-030-47150-7_2

Lundvall, B.-A., \& Johnson, B. (1994). The learning economy. Journal of Industry Studies, 1(2), 23-42. https://doi.org/10.1080/13662719400000002

Marin, B., \& Mayntz, R. (1991). Policy networks: Empirical evidence and theoretical considerations. Public Policy and Social Welfare: Vol. 9. Frankfurt: Campus. 
Mayntz, R. (2003). Governing failures and the problem of governability: Some comments on a theoretical paradigm. In J. Kooiman (Ed.), Modern governance: New government-society interactions (pp. 9-20). London: SAGE.

Meusburger, P. (2008). The nexus of knowledge and space. In P. Meusburger, M. Welker, \& E. Wunder (Eds.), Clashes of knowledge (pp. 35-90). Knowledge and Space: Vol. 1. Dordrecht: Springer. https://doi.org/10.1007/978-1-4020-5555-3_2

Niemeyer, S. (2020). Knowledge and the deliberative stance in democratic systems: Harnessing scepticism of the self in governing global environmental change. In J. Glückler, G. Herrigel, \& M. Handke (Eds.), Knowledge for governance (pp. 269-292). Knowledge and Space: Vol. 15. Cham: Springer. https://doi.org/10.1007/978-3-030-47150-7_12

Nooteboom, B. (2000). Learning by interaction: Absorptive capacity, cognitive distance and governance. Journal of Management and Governance, 4, 69-92. https://doi.org/10.102 3/A:1009941416749

Osborne, S. P. (2000). Public-private partnerships: Theory and practice in international perspective. London: Routledge.

Osborne, D., \& Gaebler, T. (1992). Reinventing government: How the entrepreneurial spirit is transforming the public sector. Reading: Addison-Wesley.

Ostrom, E. (2000). Collective action and the evolution of social norms. The Journal of Economic Perspectives, 14(3), 137-158. https://doi.org/10.1257/jep.14.3.137

Ostrom, E. (2005). Understanding institutional diversity. Princeton, NJ: Princeton University Press.

Peters, B. G. (2014). Is governance for everybody? Policy and Society, 33, 301-306. https://doi. org/10.1016/j.polsoc.2014.10.005

Pierre, J., \& Peters, B. G. (2000). Governance, politics and the state. London: Macmillan.

Podolny, J. M., \& Page, K. L. (1998). Network forms of organization. Annual Review of Sociology, 24, 57-76. https://doi.org/10.1146/annurev.soc.24.1.57

Pohlmann, M., \& Valarini, E. (2020). The fight against corruption in Brazil: A case of good governance? In J. Glückler, G. Herrigel, \& M. Handke (Eds.), Knowledge for governance (pp. 225-241). Knowledge and Space: Vol. 15. Cham: Springer. https://doi. org/10.1007/978-3-030-47150-7_10

Powell, W. W. (1991). Neither market nor hierarchy: Network forms of organization. In G. Thompson, J. Frances, R. Levacic, \& J. Mitchell (Eds.), Markets, hierarchies \& networks: The coordination of social life (pp. 265-276). London: SAGE.

Punstein, A. M., \& Glückler, J. (2020). In the mood for learning? How the thought collectives of designers and engineers co-create innovations. Journal of Economic Geography, 20, 543-570. https://doi.org/10.1093/jeg/lbz019

Raab, J., Kenis, P., Kraaij-Dirkzwager, M., \& Timen, A. (2020). Ex ante knowledge for infectious disease outbreaks: Introducing the organizational network governance approach. In J. Glückler, G. Herrigel, \& M. Handke (Eds.), Knowledge for governance (pp. 319-349). Knowledge and Space: Vol. 15. Cham: Springer. https://doi.org/10.1007/978-3-030-47150-7_14

Renn, O. (2020). Risk governance: From knowledge to regulatory action. In J. Glückler, G. Herrigel, \& M. Handke (Eds.), Knowledge for governance (pp. 93-111). Knowledge and Space: Vol. 15. Cham: Springer. https://doi.org/10.1007/978-3-030-47150-7_5

Rhodes, R. A. W. (1996). The new governance: Governing without government. Political Studies, 44, 652-667. https://doi.org/10.1111/j.1467-9248.1996.tb01747.x

Rosenau, J. N., \& Czempiel, E.-O. (1992). Governance without government. Order and change in world politics. Cambridge, UK: Cambridge University Press. https://doi.org/10.1017/ CBO9780511521775

Schultz, L., West, S., \& Florêncio, C. (2020). Nurturing adaptive governance through environmental monitoring: People, practices, politics in the Kruger to Canyons Biosphere Region, South Africa. In J. Glückler, G. Herrigel, \& M. Handke (Eds.), Knowledge for governance (pp. 293-318). Knowledge and Space: Vol. 15. Cham: Springer. https://doi. org/10.1007/978-3-030-47150-7_13 
Scott, M. (2020). Knowledge of governance as knowledge for governance: Spatialized techniques of neutralization. In J. Glückler, G. Herrigel, \& M. Handke (Eds.), Knowledge for governance (pp. 51-67). Knowledge and Space: Vol. 15. Cham: Springer. https://doi. org/10.1007/978-3-030-47150-7_3

Scott, W. R. (2007). Institutions and organizations: Ideas, interests, and identities. Thousand Oaks: SAGE.

Stehr, N. (2020). The atmosphere of democracy: Knowledge and political action. In J. Glückler, G. Herrigel, \& M. Handke (Eds.), Knowledge for governance (pp. 69-91). Knowledge and Space: Vol. 15. Cham: Springer. https://doi.org/10.1007/978-3-030-47150-7_4

Stoker, G. (1998). Governance as theory: Five propositions. International Social Science Journal, 50, 17-28. https://doi.org/10.1111/1468-2451.00106

Streeck, W., \& Thelen, K. (2005). Beyond continuity: Institutional change in advanced political economies. Oxford, UK: Oxford University Press.

Teece, D. J., Pisano, G., \& Shuen, A. (1997). Dynamic capabilities and the strategic management. Strategic Management Journal, 18, 509-533. https://doi.org/10.1002/(SICI)1097-0266 (199708) 18:7<509::AID-SMJ882>3.0.CO;2-Z

Tokatli, N. (2020). Networks as facilitators of innovation in technology-based industries: The case of flat glass. In J. Glückler, G. Herrigel, \& M. Handke (Eds.), Knowledge for governance (pp. 441-460). Knowledge and Space: Vol. 15. Cham: Springer. https://doi. org/10.1007/978-3-030-47150-7_19

van Dijk, T. A. (2014). Discourse and knowledge: A sociocognitive approach. Cambridge, UK: Cambridge University Press. https://doi.org/10.1017/CBO9781107775404

Williamson, O. E. (1991). Comparative economic organization: The analysis of discrete structural alternatives. Administrative Science Quarterly, 36, 269-296. https://doi.org/10.2307/2393356

Williamson, O. E. (2005). The economics of governance. American Economic Review, 95(2), 1-18. https://doi.org/10.1257/000282805774669880

Open Access This chapter is licensed under the terms of the Creative Commons Attribution 4.0 International License (http://creativecommons.org/licenses/by/4.0/), which permits use, sharing, adaptation, distribution and reproduction in any medium or format, as long as you give appropriate credit to the original author(s) and the source, provide a link to the Creative Commons license and indicate if changes were made.

The images or other third party material in this chapter are included in the chapter's Creative Commons license, unless indicated otherwise in a credit line to the material. If material is not included in the chapter's Creative Commons license and your intended use is not permitted by statutory regulation or exceeds the permitted use, you will need to obtain permission directly from the copyright holder. 